\title{
Alternative Investments, Sustainability in the Digital Age
}

\author{
Lin $\operatorname{Lin}^{1} \cdot$ Hans Tjio ${ }^{2}$ \\ Published online: 14 March 2020 \\ (c) T.M.C. Asser Press 2020
}

The rise of technological innovation has added complexity and new dimensions to the investment markets. The combination of financial products or services and technology is seen in different guises. These include (1) automated advice for investment and insurance; (2) the use of artificial intelligence for market trading and market resource allocation; (3) the ability to conduct payments through electronic means (e-payments); and (4) the use of block-chain technology to create decentralized means of investment (coins and tokens) and payment (e-money), and the technological regulatory responses to these developments.

Consumers are given more choice in terms of not only the financial products they subscribe to, but also the ways through which these financial services are offered. These, however, have triggered regulatory challenges, which may well be new wine in old bottles to regulators, but call for different solutions due to the nature of the technologies. Another issue is the phenomenon of over-financialization, a concern that is especially pressing in a post-Global Financial Crisis world. Sustainability is undoubtedly the desirable goal for the financial technology (FinTech) industry. But what sustainability entails and how it can be achieved require further consideration. In light of this, we are honoured to write the guest editorial for this issue of the European Business Organization Law Review on 'Alternative Investments, Sustainability in the Digital Age'.

The article by Douglas W. Arner, Ross P. Buckley, Dirk A. Zetzsche and Robin Veidt entitled 'Sustainability, FinTech and Financial Inclusion' provides an excellent overview on this topic. ${ }^{1}$ We are today increasingly reminded of Churchill's desire to make 'finance less proud and industry more content'. Financial institutions must balance their objectives such as financial stability and financial integrity with other

\footnotetext{
${ }^{1}$ Arner et al. (2020).

Lin Lin

lawll@nus.edu.sg

Hans Tjio

lawtjioh@nus.edu.sg

1 Assistant Professor, Faculty of Law, National University of Singapore (NUS), Singapore, Singapore

2 Professor, Faculty of Law, National University of Singapore (NUS), Singapore, Singapore
} 
pressing concerns such as the goals of sustainable development and the issue of climate change. How financial systems should adapt and evolve to meet these pressing concerns is also vital to the sustainability of the financial sector itself. Arner et al.'s article sheds light on how financial institutions have introduced measures to promote inclusiveness, so that financial services can be accessible to all parts of society, and how FinTech can contribute to the sustainable development goals laid down by the UN Sustainable Development Goal Resolution adopted by the General Assembly of the United Nations, entitled Transforming Our World: The 2030 Agenda for Sustainable Development.

The next two articles focus on developments in financial technology before the rest bring in sustainability concerns which in this issue are really about the financing of small and medium-sized enterprises (SMEs). Given China's rapid industrial development that is now seemingly being replicated in financial services, quite a number of articles have a China dimension to them. There is also a real-time laboratory experiment that avoids both problems with path dependency and first-mover disadvantages that exist elsewhere.

One aspect of the rise of FinTech is seen in the increasing use of block-chain technology to create new means of investment as well as exchange. New currencies have made us examine a range of issues, from the philosophical meaning of currency, to the practical effects of digital currencies (Christian Hofmann, 'The Changing Concept of Money: A Threat to the Monetary System or an Opportunity for the Financial Sector?'). ${ }^{2}$ The rise of new currencies has also seen banks considering having their own digital currencies. But these new forms of currencies, some more disruptive to the traditional sovereign-backed currencies than the others, clearly require a change in how we regulate them. There are also concerns over the control of money supply, and this may explain why some states, like China, have proposed their own digital currency.

Hence, while the rise of FinTech has a positive impact, it is accompanied by regulatory challenges. In another example, the use of robo-advisors, which has arguably sidelined traditional financial advisors in the United States (US) and China, also poses challenges to our existing legal framework (Guo Li, 'Regulating Investment Robo-Advisors in China: Problems and Prospects'). ${ }^{3}$ Accountability problems with robo-advisors require us to rethink how to apply traditional legal concepts, such as fiduciary duties and duties of disclosure, as robots and algorithms are not in any meaningful sense separate legal entities. In Guo's paper, how other countries have regulated third-party robo-advisors is discussed extensively, offering insights into how robo-advisors may be regulated to harness their fullest potential.

The rise of FinTech and financial inclusion has benefited SMEs which have faced difficulties in many countries securing traditional forms of finance such as bank loans, due to their size and high-risk profile. Tech-based SMEs have, however, found other forms of more responsive, though not necessarily patient, ${ }^{4}$ financing through

\footnotetext{
${ }^{2}$ Hofmann (2020).

3 Li (2020).

4 Mazzucato (2013).
} 
Venture Capital (VC) (Lin Lin, 'Contractual Innovation in China's Venture Capital Market'), ${ }^{5}$ private equity and tokens. Although FinTech has opened up new avenues of financing for SMEs, whether these options are viable is another subject of concern. Lin examines the financing of start-ups in China from an empirical and comparative perspective. She argues that the lack of a regulatory framework to protect VC investors and the shortage of financial tools have led to the development of self-help mechanisms through contractual innovation. At the heart of novel financing options is the issue of the sustainability of such options. Regulators may need to intervene with the necessary investor protection mechanisms if private ordering does not work.

One of the newer and more involved options of financing for SMEs is the junior stock exchange, since banks have traditionally not been lending enough to SMEs outside of jurisdictions with bank-dominated industrial groups, such as Germany and Japan. But in practice, this too is not without difficulties requiring a weighing of the costs and benefits. Xu Wenming, Shaogang Zhu and Zhicheng Wu, 'Building a Junior Stock Exchange: Lessons from China' ${ }^{6}$ describes what is still very much an experiment involving the many listings and delistings of Chinese SMEs on an exchange where shares are sometimes listed without an IPO and are intended to test the waters for valuation and regulatory purposes. The Chinese experience is very useful given all the alternative exchanges being set up in many jurisdictions worldwide, some without a clear plan as to what they hope to achieve.

The default position, as regulators play catch-up with technological growth without chilling innovation, is the regulatory sandbox approach, which first started with the Bank of England. But that may have been needed in those jurisdictions where courts are less inclined to defer to the views of regulators in statutory interpretation (Hans Tjio and Ying Hu, 'Collective Investment: Land, Crypto and Coin Schemes: Regulatory "Property"'). ${ }^{7}$ Tjio and Hu's paper considers the approach to regulating tokens and initial coin offerings in multiple jurisdictions. Token offerings are viable mechanisms for SMEs to raise finance, and yet the regulation of such, as the authors have suggested, is much needed. This cannot be done by governments alone trying to catch up with persons trying to avoid enforcement or supervision. The creators themselves must contribute to the process in order to justify their ownership or quasi-ownership of these newer, intangible forms of property or intermediate property. They cannot stand back and believe that rhetoric alone about a compelling story can create new, unregulated wealth. While the law may not matter as much as once thought, it still matters. Part of the work needed to allow technological interests to become "new property' would involve coming up with the necessary rules as 'an intangible asset only exists because the law says it does'. ${ }^{8}$ SMEs cannot be given carte blanche to run their businesses and raise financing, even as the world earnestly demands the

\footnotetext{
5 Lin (2020).

6 Xu et al. (2020).

7 Tjio and $\mathrm{Hu}(2020)$.

8 Calnan (2016), 1.30.
} 
employment they create. Regulation is necessary not only for investor protection but also to ensure the sustainability of the industry. Where tech businesses are concerned, the Financial Times has recently said that its 'self-declared exceptionalism is coming to an end" ${ }^{9}$ and so, for example, they cannot treat their workers as independent contractors instead of employees. This is important as the former Chief Justice of the Delaware Supreme Court, possibly one of the most pro-business judiciaries around, has pointed out that even large US companies in general should do much more to take the interest of employees into account in their decision making. 10

Hence, another aspect tied to the theme of sustainability is the sustainability of SMEs themselves as viable employers and investments. Smart Precision Finance may help in this respect (David C. Donald, 'Smart Precision Finance for Small Businesses Funding'). ${ }^{11}$ Donald's paper outlines the approach to targeted finance for small business funding to address the issues of transaction costs and information asymmetry, which are major obstacles to SMEs in seeking funding. The precision finance mechanism proposed by the author uses digitalization and automation to improve disclosure and reduce transaction costs. It gives lenders a better picture of the creditworthiness of the small businesses and allows fast-growing small businesses to transition smoothly into the next stage of development. This is a prime example of how technology contributes to the growth and sustainability of the SME scene, rather than just disrupting it for the benefit of financiers.

\section{References}

Arner DW, Buckley RP, Zetzsche DA, Veidt R (2020) Sustainability, FinTech and financial inclusion. Eur Bus Org Law Rev. https://doi.org/10.1007/s40804-020-00183-y (in this issue)

Calnan R (2016) Proprietary rights and insolvency. Oxford University Press, Oxford

Donald DC (2020) Smart precision finance for small businesses funding. Eur Bus Org Law Rev. https ://doi.org/10.1007/s40804-020-00180-1 (in this issue)

Hofmann C (2020) The changing concept of money: a threat to the monetary system or an opportunity for the financial sector? Eur Bus Org Law Rev. https://doi.org/10.1007/s40804-020-00182-z (in this issue)

Li G (2020) Regulating investment robo-advisors in China: problems and prospects. Eur Bus Org Law Rev. https://doi.org/10.1007/s40804-020-00187-8 (in this issue)

Lin L (2020) Contractual innovation in China's venture capital market. Eur Bus Org Law Rev. https:// doi.org/10.1007/s40804-020-00184-x (in this issue)

Mazzucato M (2013) The entrepreneurial state: debunking public vs. private sector myths. Anthem Press, London

Strine Jr L (2019) Toward Fair and sustainable capitalism: a comprehensive proposal to help American workers, restore fair gainsharing between employees and shareholders, and increase American competitiveness by reorienting our corporate governance system toward sustainable longterm growth and encouraging investments in America's future. University of Penn, Institute for Law \& Econ Research Paper No 19-39. https://ssrn.com/abstract=3461924. Accessed 11 Feb 2020

\footnotetext{
9 Richard Waters, Financial Times, 19 September 2019.

10 Strine Jr (2019).

11 Donald (2020).
} 
Tjio H, Hu Y (2020) Collective investment: land, crypto and coin schemes: regulatory 'property'. Eur Bus Org Law Rev. https://doi.org/10.1007/s40804-020-00179-8 (in this issue)

Xu W, Zhu S, Wu Z (2020) Building a junior stock exchange: lessons from China. Eur Bus Org Law Rev. https://doi.org/10.1007/s40804-020-00181-0 (in this issue)

Publisher's Note Springer Nature remains neutral with regard to jurisdictional claims in published maps and institutional affiliations. 